\title{
RIPPLE OF AGONY
}

\author{
Jennifer Gracia \\ English Department, Faculty of Letters, Petra Christian University, Surabaya, Indonesia \\ Email:m11413048@john.petra.ac.id
}

\begin{abstract}
The creative project I had written is a novel that is telling the story of a man named, Arya, who seems to be a good man while actually he has a very dark secret and past. He loves to hunt for girl in cafés and he later will do whatever he needs to do in captivating the girl's heart. When he gets the girl's heart and trust, he will do what he wants the most, the main purpose of his hunting which is overpowering the girl. In this story, I choose to write about the life of a serial rapist with the theme of love changes everything. It helps me in realizing my aim for writing this work which is to raise more awareness towards the cases of rape that happen around us. In rape cases, the victim is being sympathized while the criminal is being hated. While actually, the criminal also needs support from his surrounding in order to be a better man in the future. What I am trying to say is that we should hate his act, but not the person. In the story, Arya will see how people hate him even after he serves the fifteen years charges and willing to be a better person. As for the genre, I choose realistic fiction in order to make the story believable since it is written based on the research with the main character created according to the characteristic of serial rapist in real life.
\end{abstract}

Keywords: Realistic fiction, serial rapist, criminal.

\section{INTRODUCTION}

Rape has become one of big issues that Indonesia has to deal with. According to Catatan Fakta Tahunan (CATAHU) or Annual Recorded Fact of National Commission on Violence against Women, the numbers of sexual violence are rising to the second rank position in the data of Kekerasan Terhadap Perempuan (KTP) or Violence against Women (National Commission on Violence against Women, 2016). It can be seen through CATAHU 2014 and CATAHU 2016. From CATAHU 2014, the form of violence against women with the highest rank is physical abuse with the percentage of $40 \%$ or 3.410 cases while sexual violence is in the third rank with the percentage of $26 \%$ or 2.274 cases (National Commission on Violence against Women, 2014). Meanwhile, according to the data of CATAHU 2016, sexual violence has moved to the second rank position with the percentage of $30 \%$ or 3.325 cases and the form of sexual violence with highest rank is rape with the percentage of $72 \%$ or 2.399 cases (National Commission on Violence against Women, 2016). One of the big cases that happen in 2016 is the case of Yuyun. Yuyun (14) was raped by 14 men (age 16 to 23) and murdered (Sartika, 2016). Yuyun's body was discovered by the villagers in a village in Bengkulu province, Western Indonesia (Sartika, 2016).

The fact of rape as one of big issues that Indonesia has to face makes me interested in creating a creative work with rape as the theme. In order to decide the form of creative work that I am going to create, I begin to look for creative works with rape as theme. I remember an Indonesian novel that I had read before entitled Potions and Paper Cranes by Lan Fang, which talks about women's suffering during the end of World War II and Indonesia's transition from a Dutch to an independent republic (2013). Another example from Indonesia is a 1973 novel, Karmila by Marga Tjoa (Marga T.). Karmila talks about a young girl, a medical school student who is raped in a wild party and she has to face the reality that she has to be bound to her rapist. However, I also look for international creative works with rape theme as a comparison to Indonesian creative works. The most interesting novel that I found and had read it myself is Redeeming Love by Francine Rivers. Redeeming Love is a historical fiction book that retelling the biblical love story of Gomer and Hosea which is set against the romantic backdrop of the California Gold Rush (Rivers, 2016). The story is about a high class prostitute named Angel. She was sold to a man named Duke when she was around six or seven years old. The second one is Speak by Laurie Halse Anderson (2014). The book is about a high school student named Melinda who was raped by an upperclassman, a guy who still attends the same high school as her. 
I discover one similarity from four rape-themed novels above which is the main focus of the story that is using rape victims' point of view. The novels usually talk about the victims' feeling and the way the victims overcome the crisis. Meanwhile, the rapists in the novels are only being explained briefly and the explanation is based on the victims' point of view. For example like in the novel Speak, Melinda (the main character, the victim) addresses her rapist as 'it' which means that Melinda does not think that the rapist is part of human being.

The same with rape cases in reality where the victims are given a lot of attention. Even though the victims do not talk about their feeling or the way they overcome the crisis, but they are given the attention through their families. For example, the family will be interviewed and asked about what the police should do to the rapists. However, if there is any explanation about the rapists, the explanation only about what they have done before the rape like the rapists have consumed alcohol or drugs; the rapists have pornographic videos or pictures in their phones; or the rapists and the victims know each other through social media such as Facebook, Instagram, or other social media. This indirectly causes the society to put the blame on alcohol, drugs, pornography and social media while actually the one who responsible for the act of rape is the rapists. I do not say that I am taking side to alcohol, drugs, pornography and social media. What I think is that those things are only a small piece of aspect that has taken role in the aggressive act of the rapists. In other words, there is bigger aspect(s) that contributes to the act of rape that has not been revealed to the public.

After seeing the fact that happen in Indonesia, I think that there must be something that makes rape is difficult to beat. Yet, it turns out that there are many things that make rape almost impossible to be beaten. For example is the stigmatization of rape victims where the victims is accused for causing the rape to happen by wearing inappropriate clothes such as mini skirt (What is Rape Culture?, 2014). This stigmatization makes people think that the victims actually are asking for the rape because of the way they dress and also creates an excuse for men to rape (Buchwald, Fletcher, \& Roth, 1993). Yet, there is a cause that unconsciously or maybe consciously being ignored by people. The cause is the act of rape itself. To be more specific, the cause is the act of a man who rapes a woman like what happen in Yuyun's case. This makes me wonder about why or what causes a man heartlessly rape a girl or a woman. With the question above in mind, the result of literature research that I have explained in the second paragraph and the bigger aspect(s) that contributes to the act of rape that has not been revealed to the public, I think that writing a rape-themed novel that explores a rapist life will be both challenging and interesting. Therefore, I decide to write a rapethemed novel with the main focus on the exploration of a rapist's life.

The reason why I choose to write a novel first because I am more interested in writing a novel and second because the topic of my novel is better to be explained in the form of novel. Writing a novel has always been my dream since I was in senior high school. My parents, especially my father had introduced me to reading since I was a kid and since then I cannot stop reading books such as comics, children's books in the form of novel or picture book, young adult fiction and inspirational books when I was in junior and senior high school. I always want to be an author one day and this final project has allowed me to learn about the steps of writing a novel. Moreover, because the topic that I have chosen is exploring about the life of a rapist, I think that novel will be the most suitable form because novel will allow me to explain and describe the story vividly through the exploration of words.

From both local and international rape-themed novels that I have discovered, I can see that there are varied genres that can be used for writing a rape-themed novel. For example like historical fiction genre that is used in the novel Redeeming Love or romance genre that is used in the novel Karmila. Since I have decided to write a rape-themed novel, I think the genre of my novel will be related to real life, therefore I think that realistic fiction will be the most suitable genre for my novel. Realistic fiction is a genre consisting of stories that could have actually occurred to people or animals in a believable setting. (What is Realistic Fiction? Definition, Characteristics, \& Examples, 2016). The reason of why I use realistic fiction is because I will be able to create a fictional story that is believable for the readers because the story is written based on the research of the real cases that have been investigated by psychologists.

The facts above had made me think about writing a novel with the main focus on rape and particularly on the rapist. There are already few novels and other forms of creative work that talk about rape. Yet, the novels and the other forms are written based on the victim's perspective. 
Therefore, I decided to write a novel based on the rapist's perspective. Therefore, my statement of problem are what makes a man becomes a rapist, and how a rapist lives his life after committing the first rape and how a society's (neighbor, friends, family) negative treatment toward a rapist affects his life. Meanwhile, my purpose of study are a man can become a rapist due to a traumatic experience such as parental abuse (physical and/or sexual abuse during childhood), a rapist will or may repeat the same act without feeling guilty, and negative treatment from a society would not help a rapist becomes a better person.

The theory that I will be using in order to shape the characters and the story of my novel is the theory of rape from psychological perspective. Rape has three categories which is forced rape, statutory rape and date rape. Forced rape is sexual intercourse with an unwilling partner. Statutory rape refers to sexual intercourse with a minor or someone under the age of consent (Davison e. a., 2006). According to Indonesia's law the age of consent is 18 years old. Date rape is rape that happens between two people who know each other and may even be dating (Neale, Davison, \& Haaga, 1996). According to Abnormal Psychology $9^{\text {th }}$ Edition, rapist can be anyone under particular circumstances. The circumstances are divided into five. First is a man who primarily a psychopath who seeks thrill of dominating and humiliating a woman through intimidation and brutal assault. Second is a respectable and honored man in authority who can take advantage of his position of power over a woman. Third is a college student who inhibitions against expressing anger have been dissolved by alcohol. Fourth is an unassertive man with fragile ego who feeling inadequate after disappointment and rejection in work or love then takes out his frustration on an unwilling stranger. The last is a teenager who is provoked by a seductive and apparently available young woman who was not as interested as he in sexual intimacy (Davison, et al, 2006).

A common thing that many rapists have is unusually high hostility toward women that is arising from beliefs of having been betrayed, deceived, or demeaned by them or from exposure to parental violence and physical or sexual abuse during childhood. Other things that make the urge to rape heightened are feelings of loneliness, anger, humiliation, inadequacy, and rejection. Moreover, a rapist who has done his first rape usually will repeat it again especially if he has not been caught by the authority (Davison, et al, 2006).

In creating my main character, I used the theory I got from a psychologist, Dra. Lisa Narwastu Kristsuana, M.PSDM. According to Mrs. Lisa, a serial rapist's intention to rape is not only because of the uncontrollable sexual desire but also because of the satisfaction from dominating the victim and the satisfaction from not being caught after doing something wrong. If rapist's intention is only sexual gratification, the rapist does not need to commit a crime, the rapist can always go to a brothel, and the rapist will not be a rapist. Furthermore, one of the triggers of rape is pornography that depicts aggression toward women. In the other hand, it is also supported by the abnormal sexual desire that demands sexual gratification through violence (the act of rape). Rapists usually are smart because they need to plan and think about a very good strategy for the execution of their act. The strategy will be used for making their act untraceable. They also are smart in reading people and they know what kind of women who can be their victims.

From the interview with Mrs. Lisa, I learned that a rapist may or can have a normal or real relationship with a woman. This usually happens when the rapist has received a therapy. For example, the rapist has been caught by the police and when he serves his sentence, he will be given a therapy. Through the therapy, he will get help from the therapist to learn about the crime he has committed. He will learn to understand himself and when he finally decides to be a better person, he may have a relationship with a woman in the future. Yet, there are also a lot of sex offenders who do not want to change. Therefore, all is in the hand of the person himself, whether he wants to be a better person or not.

The methods that I use in doing research for my creative project are library research and interview. I read books about abnormal psychology especially the part that explaining about rape such as Exploring Abnormal Psychology written by John M. Neale, Gerald C. Davison, and David A. F. Haaga (1996); Abnormal Psychology $9^{\text {th }}$ Edition written by Gerald C. Davison, John M. Neale, and Ann M. Kring (2006); and promoting Sexual Responsibility and Preventing Sexual Problems by George Albee, Sol Gordon, and Harold Leitenberg (1983).

For the primary data, I have interviewed a psychologist, named Dra. Lisa Narwastu Kristsuana, M.PSDM on September $13^{\text {th }}, 2016$ and November $24^{\text {th }}, 2016$. She is a lecturer of 
Christian Family Ethics class in Petra Christian University and the head of Petra Career Center. She is known for helping troubled teenagers in a church. Also she had helped many married couples who face problems in their marriage through counseling. I ask her about the characteristics of rapist. The reason of why I ask about that is because I need to know how a rapist operates and what the reasons behind the repetition of the act of rape because there are a lot of types of rapists and each type has its own characteristics. By knowing the characteristics of rapists, so I will be able to choose the right type of rapist that I am going to write.

After learning about the theory above, I started the journey of shaping and creating my main character for my novel. I create a character that is very evil in the beginning. The readers may hate him because of what he does to girls and how he does everything. Yet, as the story goes on, the character begins to reveal his biggest secret of his life, then it will be where the readers may start to think about him from a different perspective.

In this story, I also explore about love. Love may be the most mainstream theme to be used in writing a novel. Yet, I found something interesting about love during the process of writing this novel. I found that love changes everything. It may be a common knowledge for all of us. We know that love certainly can change someone. Love has the power to change people, either for better or for worse. I had put an example for each throughout the story. I show how love can ruin someone's life, how love can heal someone's wound, how love can soften someone's heart and how love can harden someone's heart.

\section{PLOT}

\section{- Exposition}

The story begins with Arya's 'hunting' in a café. In this café, he happens to see Putri who always sits alone in the same spot which is near to the big glass window which shows the traffic on the road. Arya tries to be friend with her and when Putri starts to show signs of being attracted to him. Arya will try his best to make her fall in love with him then ask her to be his girlfriend. Arya treats Putri very well and makes her feel like being a princess, 'his' princess.

\section{- Point of Attack}

One day when Arya is about to take Putri to his apartment for a romantic dinner and get what he wants the most, Rama sees them in the car and knocks on the car window. He looks furious. Putri asks Arya to drive away. Later that night, Arya rapes Putri and few days later Putri runs away from her house.

\section{- Rising Action}

Arya cleverly pretends to be calm in front of Rama, as if there is nothing wrong that he has done to Putri that causes Putri's runaway. Arya then pays someone, an informant, to follow Rama so that Arya can anticipate if Rama finds out about what he has done to Putri. Nothing suspicious that is reported to Arya and Arya knows that Putri has not been found until now. Arya thinks Rama eventually will give up and he finally will be free from living with fear. Yet, everything turns upside down when Arya happens to meet Anin, his first victim, in a café. Arya pretends not to know her, walks away, and takes a seat in the corner of the café. Few minutes later when he is busy with his phone, Anin throws a glass of coffee to his face. Arya is surprised especially when he sees that Anin is the one who does that. Arya glares at Anin while Anin puts the glass on the table and leaves the café.

Few days later, Arya gets information from his informant that Rama is meeting Anin in a café. Arya is very angry and commands his informant to follow Anin and tracks where she lives. At evening, Arya goes to Anin's new address and knocks on the door. Arya forces to enter Anin's house when Anin wants to close the door. He interrogates her about what she has said to Rama in the café. When Anin does not gives the proper answer, Arya reminds her of what he had done to her in the past and that he can easily do it again. He says that Anin does enjoy what he did to her back then. Arya keeps Anin prisoned in her own house so that she cannot go and do whatever she has planned before with Rama. Arya does not realize that he is making a mistake with keeping Anin prisoned.

Arya is still sleeping when he hear a very loud noise. The door is crashed and lots of police are searching the house. Arya immediately opens the window in Putri's apartment and gets out from there. He succeeds to reach the next room but when he is about to break the window to get in, his slips and he has to be hanging on to the window's frame. He thinks that he just needs to let go of the 
grip so he does not need to face the justice. He let go of his grip, intending to kill himself. Yet, the police downstairs have prepared a rescuer and he survives. Arya is charged for 15 years of prison and his case becomes headlines everywhere. Five of his victims, including Putri, Anin, and Amanda, testify against him and prove him guilty.

Fifteen years later, Arya is released and goes back to his neighborhood. He tries hard to be a better person by starting to look for a job and stay out from other people's life. He finds some difficulties in looking for a job until he finally gets one. He faces other difficulties such as nightmares, unbearable sexual desires, and insomnia. He tried to overcome all of those difficulties by using sleeping pills.

- Climax

Everything changes when Arya meet Wulan who later encourages him to not giving up in becoming a better person.

- Falling Action

Arya goes to counseling sessions and figuring out his life.

- Resolution

Arya finally forgives his father and continues rebuilding his life with Wulan.

\section{CHARACTERS \\ Main Character \\ Arya Lesmono}

He is a man who loves to trick girls. He really likes it when girls are stupidly falling into his trap. He usually will look for a victim in a coffee shop or mall but his most favorite place to hunt is coffee shop because girls are easier to be approached when they are just chilling and enjoying the break time in a coffee shop. Mostly he hunts during lunch time because lots of college girls are hanging out with their friends in coffee shops. If the girl does not take the bait, he will just look for someone else. He also knows types of girl who usually will fall into the trap. A lonely girl who does not have friend, a nerd or bookworm, or a cheesy girl who will easily fall in love with him because of the presents or surprises he gives. He definitely will not approach a girl who seems tough or bold. He does all of that not without any reason. Something happened in his childhood and it made him becomes the man he is now.

\section{Side Characters \\ Putri Permatasari}

She is a college student studying English Literature. She is a loner. She loves to sit in a café and watching people around her. She is naïve and always thinks that all people are good and kind. She has a problem with insecurity. She feels that she is unattractive so that no men will want to go out with her. Arya is the first man who later date her and that makes her very happy. She really trusts him because he makes her happy.

\section{Rama Putra}

He is Putri's brother. He works as a programmer in a company. He really loves his sister and will do anything to make her happy. He often treats Putri likes a little girl because he is afraid that people might hurt her so he does not allow her sister to have a date or hang out with her friend. Since their parents died, he becomes more and more protective toward Putri because she is the only person he has in the world.

\section{Aninditha Raharja}

Anin is a graduate of law school. She is currently working on getting a lawyer license. She is a person who shares past memories with Arya and she knows a lot about Arya. She knows who Arya is.

\section{Wulandari Harsono}

She is a woman who just separated with her ex-husband, a mother to thirteen year old girl. She is just back from Australia where she used to live with her ex-husband and she is currently looking for a new place to start her 'new' life. She regularly visits the café where Arya works and she talks to him the first time she visits the place. She likes Arya and later on she will be the one who will be a person who matters the most for Arya. 
She is a loving person who supports Arya, loves him purely, and sees him as who he is in the present. She does not care about his past. She always supports Arya with positive thoughts and many other positive things.

She becomes the woman she is today because of what she experienced in the past. She used to be the person who worked for a big and most wanted drug dealer in Australia until one day she chose to leave everything behind and started a new life with her ex-husband. Yet, everything turned upside down when she discovered a horrible truth about her health.

\section{SETTING}

The setting of my novel will be in Surabaya.

Café(s)

Café will be the place where Arya looks for his prey.

\section{Arya's apartment - Tenggilis}

Place where Arya lives

\section{Medaeng Jail}

Place where are lives when he serves fifteen years of jail.

\section{CONCLUSION}

\section{Lesson learned}

In the process of writing the story, I learned some new things that I have never experienced before. For instance, I learn how to make plot for my story in order to have a good structure. Without creating the structure of the story, I would not be able to work on my novel according to the purpose of creative work. I also learned how to do research for creating the characters, especially the main character of the story. In creating my main character, I use the theory that I got from a psychologist who helped me by giving a lot of information about a serial rapist profile and characteristics. I also discovered that writing a novel is very challenging and interesting.

Another thing that I learned is that both rapist and victim should get help from their surroundings. I believe that there must be reasons behind the act of rape and that it must be revealed in order to help the rapist be a better person. I also learned that it is better to say 'do not rape' instead of 'do not get raped'. It means that it is better to 'cure' the problem instead of trying to avoid the problem.

\section{Future plans}

In the future, I am planning to make this novel to be better so that I can make it into a publishable book. I will also work on creating other book that is connected to this novel, for instance a book that is written from the point of view of my main character's victims. Hopefully in the future I can find a publisher that willing to publish an English novel in Indonesia because there are not a lot of publisher in Indonesia that willing to do so. However, if I can find a foreign publisher, it will be even better.

\section{REFERENCES}

(2013). Retrieved September 7, 2016, from https://books.google.co.id/books/about/Potions_and_Paper_Cranes.html?id=EYvsnQEACAAJ \&redir_esc $=\mathrm{y} \& \mathrm{hl}=\mathrm{id}$

Buchwald, E., Fletcher, P. R., \& Roth, M. (1993). Transforming a Rape Culture . Milkweed Editions.

Davison, e. a. (2006). Abnormal Psychology (9th edition ed.). USA: John Wiley \& Sons, Inc.

National Commission on Violence against Women. (2014). Retrieved September 16, 2016, from komnasperempuan.go.id: http://www.komnasperempuan.go.id/wpcontent/uploads/2015/03/Lembar-Fakta-Catatan-Tahunan-CATAHU-Komnas-PerempuanTahun-2014.pdf 
National Commission on Violence against Women. (2016, March 9). Retrieved August 18, 2016, from komnasperempuan.go.id: http://www.komnasperempuan.go.id/lembar-fakta-catatantahunan-catahu-2016-7-maret-2016/

Neale, J. M., Davison, G. C., \& Haaga, D. A. (1996). Exploring Abnormal Psychology. Canada: John Wiley \& Sons, Inc.

Rivers, F. (2016). Francine Rivers. Retrieved August 13, 2016, from francinerivers.com: http://francinerivers.com/books/redeeming-love/

Sartika, D. (2016, May 14). Yuyun and Our Ignorance. Retrieved September 7, 2016, from The Jakarta Post: http://www.thejakartapost.com/news/2016/05/14/yuyun-and-our-ignorance.html

What is Rape Culture? (2014). Retrieved August 30, 2016, from Women against Violence against Women: http://www.wavaw.ca/what-is-rape-culture/

What is Realistic Fiction? Definition, Characteristics, \& Examples. (2016). Retrieved December 20, 2016, from study.com: http://study.com/academy/lesson/what-is-realistic-fictiondefinition-characteristics-examples.html 